\title{
MENINGKATKAN PEMAHAMAN GURU DALAM MENYUSUN INSTRUMEN TES MELALUI MODEL PELATIHAN SSOTT DI SDN 003 TELUK SEBONG
}

\author{
Nurita \\ SD Negeri 003 Teluk Sebong \\ Emai: nnurita1964@gmail.com
}

\begin{abstract}
Abstrak
Guru adalah poros utama pendidikan. Ia menjadi penentu kemajuan suatu negara di masa depan. Secara umum, tugas guru adalah mengajar siswa-siswi agar memilki pengetahuan dan keterampilan dalam masing-masing bidang pelajaran.Tujuan penelitian ini untuk meningkatkan kompetensi guru dalam menyusun instrumen tes. Kompetensi guru menyusun instrumen tes adalah pengetahuan, kemampuan dan keterampilan yang harus dimiliki oleh guru untuk menyusun alat yang digunakan untuk mengukur kemampuan peserta didik setelah melakukan proses belajar mengajar melalui kegiatan penilaian. Penelitian menggunakan metode PTS. Model penelitian tindakan yang digunakan adalah model Kemmis McTaggart dengan proses siklus terdiri atas empat langkah yaitu perencanaan, pelaksanaan tindakan, pengamatan dan refleksi. Meningkatkan kompetensi guru menyusun instrumen tes menggunakan model pelatihan SSOTT. Subyek penelitian melibatkan guru SD Negeri 003 Teluk Sebong berjumlah 30 orang yang berada di Kabupaten Bintan. Indikator untuk mengukur kompetensi guru menyusun instrumen tes adalah : (1) membuat kisi-kisi soal, (2) merangkai soal, dan (3) menganalisis soal. Peningkatan kompetensi guru pada setiap siklus yaitu persentase nilai pembuatan kisi-kisi soal mengalami kenaikan yang ditunjukkan dari hasil penilaian yaitu 213,67 pada siklus pertama dan 228,33 pada siklus kedua. Persentase nilai merangkai soal mengalami kenaikan yaitu, 319,97 pada siklus pertama dan 335,03 pada siklus kedua. Persentase nilai menganalisis soal mengalami kenaikan yaitu 307,00 pada siklus pertama dan 521,00 pada siklus kedua. Hasil penelitian ini menemukan bahwa model pelatihan SSOTT dapat meningkatkan kompetensi guru menyusun instrumen tes.
\end{abstract}

\section{Kata Kunci : Pemahaman Guru, Instrumen Tes, ModeL Pelatihan SSOTT}

\section{PENDAHULUAN}

Guru adalah tenaga pendidik profesional di bidangnya yang memiliki tugas utama dalam mendidik, mengajar, membimbing, memberi arahan, memberi pelatihan, memberi penilaian, dan mengadakan evaluasi kepada peserta didik yang menempuh pendidikannya sejak usia dini melalui jalur formal pemerintahan berupa Sekolah Dasar hingga Sekolah Menengah. (Undang Undang No 14 Tahun 2005)

Seorang guru harus mampu memandang perubahan jauh ke depan, dengan demikian guru dapat merencanakan apa yang terbaik untuk anak didiknya. Seorang guru juga harus dapat mengemban tugasnya sebagai motivator yang mampu memotivasi anak didiknya agar penuh semangat dan siap menghadapi serta menyongsong perubahan hari esok. Peran seperti inilah yang disebut oleh Presiden Soekarno, sebagai "Guru di dalam arti yang spesial, yakni menjadi pembentuk akal dan jiwa anak-anak."
Penilaian merupakan istilah yang terdiri dari metode yang biasa digunakan untuk mengetahui belajar siswa dengan cara menilai unjuk kerja individu peserta didik atau kelompok (Haryati, 2009). Penilaian hasil belajar dilakukan dalam bentuk ulangan harian, ulangan tengah semester, ulangan akhir semester, dan ulangan kenaikan kelas (Sofiana, 2010).

Di samping taraf kesulitan, guru sering kali tidak memperhatikan indikator yang ingin dicapai dalam merencanakan ulangan harian. Guru perlu menyusun silabus kisi-kisi (sistem) penilaian berdasarkan prinsip yang berorientasi pada pencapaian kompetensi. Sehingga dapat menjadi pedoman guru dalam menyusun butir soal Ulangan Harian. Untuk dapat menyusun Butir Soal Ulangan Harian yang memenuhi persyaratan cukup sulit karena menyusun butir soal ulangan harian memerlukan pengetahuan, keterampilan serta ketelitian yang cukup tinggi. 
Menurut Purwanto (1997:138), guru adalah orang yang diserahkan tanggung jawab sebagai pendidik dilingkungan sekolah. Menurut Husnul Chotimah (2008) guru adalah mereka yang memfasilitasi transisi dari pengetahuan dari sumber belajar ke peserta didik. Dri Atmaka (2003), guru adalah orang yang bertanggung jawab untuk memberikan bantuan kepada siswa dalam pengembangan baik fisik dan spiritual. E. Mulyasa (2003) pendidik atau guru haru memiliki kualitas akademik dan kompetensi sebagai agen pembelajaran, sehat jasmani dan rohani, serta memiliki kemampuan untuk mewujudkan tujuan pendidikan. Ahmad (1977) pendidik adalah sebagai mengawasi peran dalam melaksanakan proses pembelajaran.

Dari pernyataan tersebut dapat kita simpulkan bahwa Guru adalah sebuah profesi yang mulia karena di tangan merekalah masa depan bangsa ini ditentukan. Guru juga dianggap sebagai pahlawan pembangunan, karena di tangan mereka akan lahir pahlawan-pahlawan pembangunan yang kelak mengisi ruang-ruang publik di negeri ini. Guru yang ideal, bukan sekedar guru yang memenuhi syarat-syarat teknik: seperti pintar, pandai, atau pakar di bidang ilmu yang dimiliki; melainkan yang jauh lebih penting dari itu semua, guru harus bisa menempatkan dirinya sebagai "agent of change".

Tes tertulis adalah tes yang soal dan jawabannya diberikan dalam bentuk tulisan. Dalam menjawab soal, peserta didik tidak harus selalu merespons dalam bentuk jawaban, tetapi bisa dalam bentuk lain seperti memberi tanda, mewarnai, menggambar dan sejenisnya. Tes tertulis sering disebut paper and pencil test.

Menurut Suharsimi Arikunto (2005:162) tes dibedakan menjadi dua yaitu tes objektif dan tes subjektif. Bentuk soal tes objektif adalah piliha ganda, pilihan benar-salah, menjodohkan, isian atau melengkapi dan jawaban singkat. Soal tes subjektif berbentuk soal uraian.

Menurut Sugiyono (2011:119) instrumen adalah alat untuk mengukur informasi atau melakukan pengukuran. Mardapi (2012:108) menjelaskan bahwa tes merupakan salah satu bentuk instrumen yang digunakan untuk melakukan pengukuran. Tes terdiri dari sejumlah pertanyaan, tujuan melakukan tes adalah untuk mengetahui pencapaian belajar atau kompetensi yang telah dicapai oleh peserta didik untuk bidang tertentu.

Menurut Mardapi (2012:119) pada tes bentuk pilihan ganda memiliki stem dan pilihan jawaban/option. Stem adalah pernyataan berupa informasi di awal soal. Pedoman utama dalam pembuatan butir soal pilihan ganda adalah sebagai berikut: (1) pokok soal harus jelas, (2) pilihan jawaban homogen dalam arti luas, (3) panjang kalimat jawaban relatif sama, (4) tidak ada petunjuk jawaban benar, (5) hindari penggunaan pilihan jawaban: semua benar atau semua salah, (6) pilihan jawaban angka diurutkan, (7) semua pilihan jawaban logis, (8) jangan menggunakan negatif ganda, (9) kalimat yang digunakan sesuai dengan tingkat perkembangan peserta tes, (10) Bahasa Indonesia yang digunakan baku, dan (11) letak pilihan benar ditentukan secara acak

Nadler(1983:7) mengetengahkan tiga jenis program belajar yaitu: (1) latihan, yaitu belajar yang berkenaan dengan pekerjaan individu sekarang, (2) pendidikan, yaitu belajar yang berkenaan dengan masadepan, tetapi pekerjaan bagi individu peserta didik tersebut dikenali dan dipersiapkan, dan (3)pengembangan, yaitu belajar bagi pertumbuhan individu atau organisasi secara umum.

Pelatihan dapat meningkatkan kompetensi guru, berdasarkan penelitian yang dilakukan oleh Sukoco (2010:82) pada guru SMP RSBI di Kota Semarang diketahui bahwa pendidikan dan pelatihan memiliki pengaruh yang positif dan signifikan terhadap kompetensi guru. Pelatihan yang efektif diterapkan kepada guru adalah pelatihan yang tidak mengganggu tugas rutin guru di sekolah dan materi pelatihan dapat langsung diterapkan oleh guru kepada peserta didik.

Model pelatihan SSOTT adalah suatu model pelatihan yang dilakukan secara bertahap dan ditujukan kepada guru untuk meningkatkan kompetensi melakukan pekerjaan tertentu. Model pelatihan SSOTT tidak mengharuskan guru meninggalkan tugas rutinnya di sekolah. Guru yang dilatih dituntut untuk menerapkan langsung kompetensi yang didapatkannya melalui pelatihan kepada peserta didik. Materi pelatihan dan aplikasinya dalam model pelatihan SSOTT dilaksanakan melalui tahapan demi tahapan (step by step) yang sangat teratur disesuaikan dengan kondisi guru pada saat pelatihan.

Dessler (2006:286) mengemuka kan agar on-the-job training berhasil ada tahap-tahap (step by step) yang perlu diperhatikan, yaitu Tahap 1: Persiapkan orang yang belajar (peserta pelatihan) yaitu : (a) Buatlah peserta pelatihan merasa nyaman, jangan sampai ada ketegangan. (b) Jelaskan mengapa peserta pelatihan harus 
belajar. (c) Dorong minat peserta pelatihan untuk bertanya, carilah apa yang diketahui oleh peserta pelatihan tentang pekerjaan. (d) Jelaskan proses seluruh pekerjaan dan hubungan beberapa pekerjaan yang telah diketahui oleh peserta pelatihan. (e) Tempatkan peserta pelatihan pada posisi kerja yang normal. (f) Perkenalkan peralatan, bahan, perangkat, dan syarat administrasi. Tahap 2: Perlihatkan cara melaksanakan pekerjaan, yaitu : (a) Jelaskan persyaratan kuantitas dan kualitasnya. (b) Lakukanlah pekerjaan itu dengan kecepatan kerja yang normal. (c) Lakukanlah pekerjaan itu dengan kecepatan lambat untuk beberapa kali, agar dapatmenjelaskan setiap langkahnya. Sambil melaksanakannya, jelaskan bagianbagian yang sulit, atau bagian dimana kesalahan mungkin terjadi. (d) Sekali lagi ulangi pekerjaan itu dengan kecepatan lambat beberapa kali, jelaskan hal-hal yang penting. (e) Biarkan peserta pelatihan menjelaskan langkah-langkah yang dilakukan saat trainer melakukan pekerjaan itu dengan kecepatan lambat. Tahap 3: Lakukanlah ujicoba, yaitu : (a) Biarkanlah peserta pelatihan melakukan pekerjaan tersebut beberapa kali, secara perlahan, sambil menjelaskan setiap langkahnya kepada trainer.

Perbaikilah kesalahannya, dan bila perlu, lakukanlah beberapa langkah rumit pada beberapa kali pertama. (b) Lakukanlah pekerjaan itu dengan kecepatan normal. (c) Biarkan peserta pelatihan melakukan pekerjaan tersebut, yang secara bertahap akan membangun keterampilan dan kecepatan. (d) Segera peserta pelatihan memperlihatkan kemampuannya dalam melakukan pekerjaan itu, biarkanlah pekerjaan tersebut dimulai, tetapi jangan meninggalkannya Tahap 4: Tindak lanjut, yaitu : (a) Beritahukanlah kepada siapa peserta pelatihan minta tolong. (b) Secara bertahap kurangilah pengawasan, periksalah pekerjaan itu dari waktu ke waktu atas standar kualitas dan kuantitas. (c) Perbaikilah pola kerja yang salah sebelum terlanjur menjadi kebiasaan. Perlihatkanlah mengapa metode yang dipelajari lebih baik. (d) Berikan pujian untuk pekerjaan yang baik, doronglah peserta pelatihan hingga mampu memenuhi standar kualitas dan kuantitas.

Langkah-langkah model pelatihan SSOTT pada PTS ini adalah : 1. Step by step materi, materi yang disampaikan pada saat pelatihan dilakukan secara bertahap dan langkah demi langkah penyusunan instrumen tes hasil belajar.2. Step by step penerapan, penerapan materi yang disampaikan pada saat pelatihan dipraktikkan dan diaplikasikan langsung kepada peserta didik. 3. Step by step lokasi, lokasi tempat subjek penelitian ada beberapa sekolah.

Penyelenggaraan pelatihan dilaksanakan di sekolah. Pengawas sekolah dan peneliti secara bertahap mengunjungi sekolah-sekolah tempat guru mengajar untuk melakukan pelatihan. 3 . Step by step proses, proses pelatihan dilakukan dengan beberapa kali pertemuan, selama perlatihan berlangsung guru dituntut dapat mempraktikkan materi.

\section{METODE PENELITIAN}

Subyek pada penelitian ini adalah guru guru Sekolah Dasar Negeri 003 Teluk Sebong berjumlah 30 orang

Lokasi Penelitian ini lakukan di SDNegeri 003 Teluk Sebong Kecamatan Telok Sebong Kabupaten Binta Provensi Kepulauan Riau. Terletak di jalan Pancamarga no1 Desa Sebong Lagoi Sungai Kecil Kecamatan Teluk Sebong Waktu pelaksanaan penelitian ini adalah selama 2 bulan yaitu dimulai tanggal, 4 Januari 2019 Januari s/d 29 Febuari 2019

Penelitian ini menggunakan Penelitian Tindakan Sekolah PTS, Tindakan pelatihan dilakukan minimal dua siklus tindakan yaitu siklus I dan siklus II. Pelaksanaan pelatihan siklus II didasarkan dari hasil refleksi siklus I. Siklus II merupakan tindakan untuk memperbaiki dan menyempurnakan tindakan yang telah dilaksanakan pada siklus I agar kompetensi guru menyusun instrumen tes mencapai indikator keberhasilan.

Desain yang digunakan dalam penelitian ini adalah penelitian tindakan sekolah (PTS). Tindakan yang dilakukan adalah bentuk pelatihan dengan model SSOTT yang bertujuan meningkatkan kompetensi guru untuk menyusun instrumen tes hasil belajar. Penelitian menggunakan model Kemmis McTaggart yang dirancang dengan proses siklus yang terdiri dari empat fase kegiatan yaitu merencanakan (planning), melakukan tindakan (action), mengamati (observation), dan merefleksi (reflectif). Tahap-tahap ini terus berulang sampai permasalahan teratasi atau indikator keberhasilan telah tercapai.

Sesuai dengan jenis penelitian yang dipilih, yaitu penelitian tindakan, maka penelitian ini menggunakan model penelitian tindakan dari Kemmis dan Taggart (dalam Sugiarti, 1997: 6), yaitu berbentuk spiral dari sklus yang satu ke siklus yang berikutnya. Setiap siklus meliputi planning (rencana), action (tindakan), 
observation (pengamatan), dan reflection (refleksi). Langkah pada siklus berikutnya adalah perncanaan yang sudah direvisi, tindakan, pengamatan, dan refleksi. Sebelum masuk pada siklus 1 dilakukan tindakan pendahuluan yang berupa identifikasi permasalahan. Siklus spiral dari tahap-tahap penelitian tindakan kelas dapat dilihat pada gambar berikut.

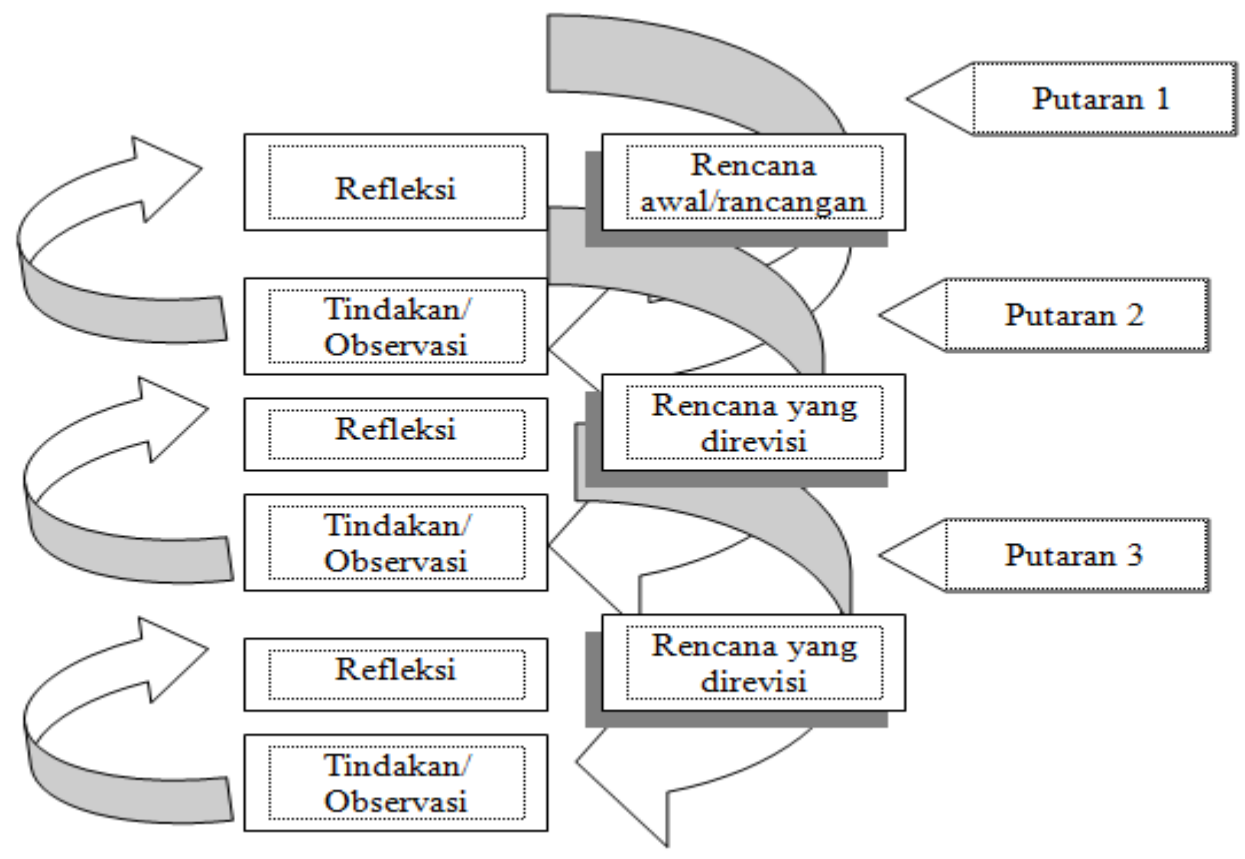

Gambar 1. Model Penelitian Tindakan Dari Kemmis dan Taggart

Indikator sebagai ukuran keberhasilan tindakan yang dilakukan dalam setiap siklus penelitian adalah apabila kompetensi guru berada pada kategori sangat baik (mendapatkan skor $\geq 86$ ) dan jumlah guru yang berada pada kategori sangat baik atau sama dengan $80 \%$.

\section{HASIL DAN PEMBAHASAN PENELITIAN Prasiklus}

Data yang didapatkan dari prasiklus diambil dari hasil observasi guru-guru SD Negeri 003 Teluk Sebong. Dari hasil observasi dari 30 orang guru belum mampu menyusun instrumen tes dengan baik. Hasil penilaian pada prasiklus yang dilakukan oleh peneliti terhadap tingkat kompetensi guru adalah 21 atau $70 \%$ orang guru kompetensi menyusun instrumen tes berkategori kurang dan 9 atau $30 \%$ orang guru kompetensi menyusun instrumen tes berkategori cukup. Hal ini dikarenakan belum adanya pelatihan yang pernah diikuti oleh guru- guru yang ada di SDN 003 Teluk Sebong Kecamatan Teluk Sebong. Sehingga perlu kiranya mengadakan persiapan siklus 1 untuk mengatasi masalah yang di hadapi guru-guru tersebut.

Tabel 1. Tingkat Kecenderungan Kompetensi Guru Menyusun Instrumen Tes Pada Prasiklus

\begin{tabular}{ccccc} 
No & Interval Kelas & $\begin{array}{c}\text { Frekuensi } \\
\text { Observasi }\end{array}$ & $\begin{array}{c}\text { Frekuensi } \\
\text { Relatif }\end{array}$ & Kategori \\
\hline 1 & $32.50-40.00$ & 0 & $0.00 \%$ & Sangat baik \\
\hline 2 & $25.00-32.49$ & 0 & $0 \%$ & Baik \\
\hline 3 & $17.50-24.99$ & 9 & $30 \%$ & cukup \\
\hline 4 & $10.00-17.49$ & 21 & $70 \%$ & kurang \\
\hline
\end{tabular}

Distribusi frekuensi skor kompetensi guru bentuk diagram batang seperti gambardiagram menyusun instrumen tes ditampilkan dalam batang berikut ini. 


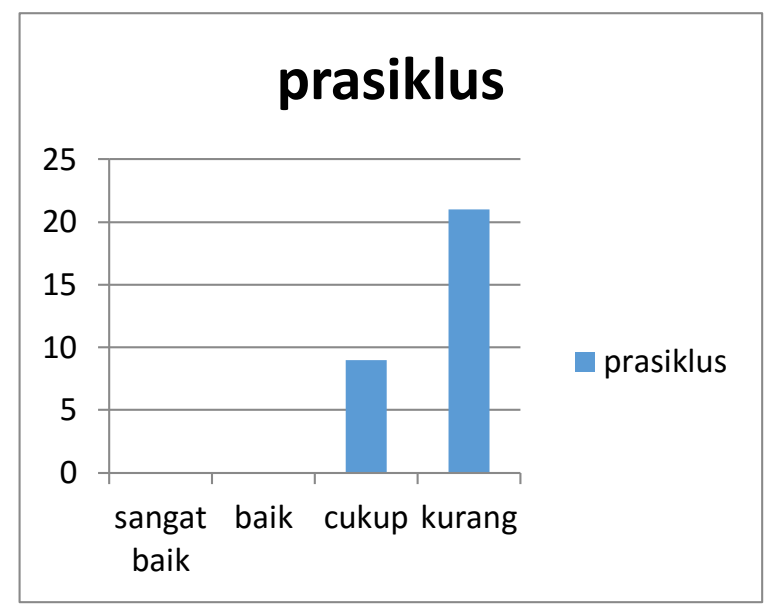

\section{Siklus 1}

Tindakan pada siklus I direncanakan dilaksanakan pada tanggal 4 - 25 Januari 2019. Pelaksanaan tindakan siklus I sebanyak tiga pertemuan. Hasil penilaian yang dilakukan peneliti terhadap kompetensi guru menyusun instrumen tes selama mengikuti pelatihan adalah sebagi berikut dalam menyusun instrumen tes adalah 29 atau $96,67 \%$ orang guru kompetensi menyusun instrumen tes berkategori baik dan 1 atau $3,33 \%$ orang guru kompetensi menyusun instrumen tes berkategori cukup. Hal ini dapat dilihat pada tabel berikut ini.

Tabel 2. Tingkat Kecenderungan Kompetensi Guru Menyusun Instrumen Tes Pada Siklus I

\begin{tabular}{lllll}
\hline No & Interval Kelas & $\begin{array}{l}\text { Frekuensi } \\
\text { Observasi }\end{array}$ & Frekuensi Relatif & Kategori \\
\hline 1 & $32.50-40.00$ & 0 & $0.00 \%$ & Sangat baik \\
\hline 2 & $25.00-32.49$ & 29 & $96.67 \%$ & Baik \\
\hline 3 & $17.50-24.99$ & 1 & $3.33 \%$ & cukup \\
\hline 4 & $10.00-17.49$ & 0 & $0.00 \%$ & kurang \\
\hline & Total & 30 & $100 \%$ & \\
\hline
\end{tabular}

Distribusi frekuensi skor kompetensi guru menyusun instrumen tes ditampilkan dalam bentuk diagram batang seperti gambardiagram batang berikut ini.

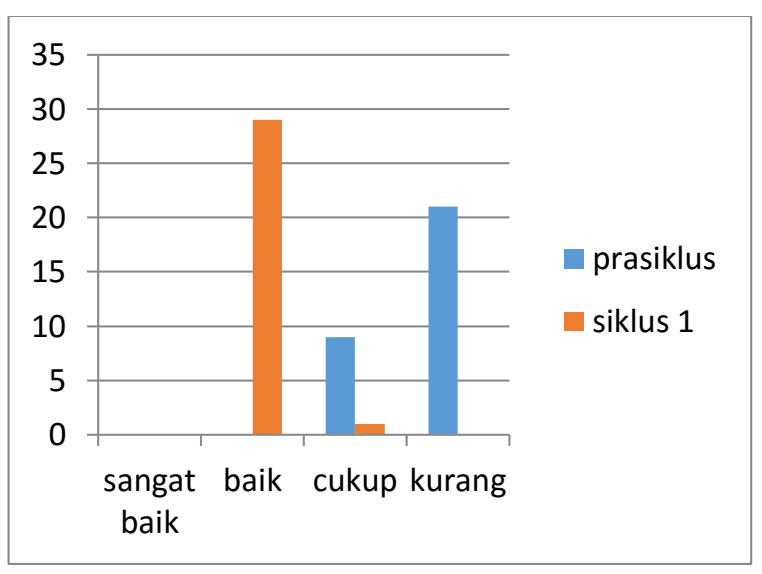

Gambar 1 Diagram Batang Kompetensi Guru Menyusun
Tingkat ketercapaian masing-masing guru pada aspek syarat kisi-kisi yang sangat baik, merumuskan indikator, materi soal, konstruksi soal dan bahasa soal sudah berada pada kategori sangat baik. Aspek yang belum mencapai kategori sangat baik yaitu analisis tingkat kesukaran, analisis daya pembeda analisis efektivitas pengecoh, analisis validitas butir soaldan analisis reliabilitas soal. Secara rinci kompetensi guru untuk setiap aspek pada indikator kompetensi menyusun instrumen tes dapat dilihat pada table 2 berikut ini :

Tabel 3. Tingkat Ketercapaian Setiap Aspek Pada Indikator Menyusun Instrumen Tes Siklus I

\begin{tabular}{|c|c|c|c|c|c|}
\hline No & Indikator & Aspek & Skor Total & $\begin{array}{l}\text { Rata-rata } \\
\text { Skor }\end{array}$ & Klasifikasi \\
\hline 1 & Membuat Kisi- & Syarat Kisi-Kisi & 320.00 & 3.56 & Sangat Baik \\
\hline
\end{tabular}




\begin{tabular}{|c|c|c|c|c|c|}
\hline & \multirow{2}{*}{ kisi Soal } & \multicolumn{4}{|l|}{ yang Baik } \\
\hline & & $\begin{array}{l}\text { Merumuskan } \\
\text { Indikator }\end{array}$ & 318.00 & 3.53 & Sangat Baik \\
\hline \multirow[t]{3}{*}{2} & Merangkai Soal & Materi & 322.60 & 3.58 & Sangat Baik \\
\hline & & Konstruksi & 319.00 & 3.54 & Sangat Baik \\
\hline & & Bahasa & 318.30 & 3.54 & Sangat Baik \\
\hline \multirow[t]{5}{*}{3} & Analisis Soal & Tingkat Kesukaran & 195.00 & 2.17 & cukup \\
\hline & & $\begin{array}{l}\text { EfektiVitas } \\
\text { Pengecoh }\end{array}$ & 273.00 & 3.03 & baik \\
\hline & & Daya Pembeda & 180.00 & 2.00 & cukup \\
\hline & & $\begin{array}{l}\text { Validitas Butir } \\
\text { Soal }\end{array}$ & 180.00 & 2.00 & cukup \\
\hline & & Reliabilitas Soal & 93.00 & 1.03 & kurang \\
\hline
\end{tabular}

Refleksi pertama yaitu kompetensi guru menyusun instrumen tes belum ada yang mencapai kategori baik. 29 atau $96,67 \%$ orang guru kompetensi menyusun instrumen tes berkategori baik dan 1 atau 3,33\% orang guru kompetensi menyusun instrumen tes berkategori cukup. Tingkat ketercapaian masing-masing guru pada aspek syarat kisi-kisi yang sangat baik, merumuskan indikator, materi soal, konstruksi soal dan bahasa soal sudah berada pada kategori sangat baik. Aspek yang belum mencapai kategori sangat baik yaitu analisis tingkat kesukaran, analisis daya pembeda analisis efektivitas pengecoh, analisis validitas butir soaldan analisis reliabilitas soal.

Refleksi kedua yaitu pelaksanaan model pelatihan SSOTT belum terlaksana dengan baik. Kekurangan pelaksanaan model pelatihan SSOTT adalahguru tidak mau bertanya ketika mengalami kesulitan menghadapi materi pelatihan karena kurangnya dorongan dari peneliti untuk memberikan kesempatan kepada guru untuk bertanya.

Pelaksanaan pelatihan siklus I hanya ada dua pertanyaan dari guru peserta pelatihan. Peneliti menyepakati perlu adanya perubahan pada pelaksanaan pelatihan. Siklus II pelaksanaan pelatihan lebih mengintensifkan bimbingan secara individual, dengan cara ini peneliti dapat mengidentifikasi kesulitankesulitan yang dialami oleh guru.

Kesimpulan refleksi pertama dan kedua pada siklus I adalah ada peningkatan kompetensi yang dialami guru selama pelaksanaan tindakan siklus I dibandingkan prasiklus. Peneliti sepakat untuk melanjutkan ke siklus II. Kekurangan pelaksanaan model pelatihan SSOTT siklus I akan disempurnakan pada siklus II. Materi pelatihan yang akan disampaikan pada siklus II sama dengan materi siklus I yang menjadi perhatian serius pada siklus II adalah materi analisis soal karena pada materi ini belum ada aspek yang berkategori sangat baik Siklus 2

Tindakan pada siklus II dilaksanakan pada tanggal 1 - 22 Februari 2019. Perencanaan tindakan siklus II peneliti mendiskusikan permasalahan-permasalahan yang dihadapi guru pada siklus I. Pelaksanaan tindakan siklus II dilaksanakan sebanyak tiga pertemuan. Pelaksanaan siklus II peneliti merubah konsep pelaksanaan pelatihan sesuai dengan refleksi yang dilakukan pada siklus I. Pendekatan secara individual akan lebih diutamakan daripada penjelasan materi yang terlalu terpusat kepada narasumber (peneliti).

Hasil penilaian yang dilakukan oleh oleh peneliti terhadap kompetensi guru menyusun instrumen tes setelah pelaksanaan tindakan pada siklus II dalam menyusun instrumen tes adalah 26 atau $86,67 \%$ orang guru kompetensi menyusun instrumen tes berkategori sangat baik dan 4 atau $13,33 \%$ orang guru kompetensi menyusun instrumen tes berkategori baik. Hal ini dapat dilihat pada tabel berikut ini. dapat dilihat pada tabel 3 berikut ini. 
Tabel 4. Tingkat Kecenderungan Kompetensi Guru Menyusun Instrumen Tes Pada Siklus II

\begin{tabular}{ccccc}
\hline No & Interval Kelas & $\begin{array}{c}\text { Frekuensi } \\
\text { Observasi }\end{array}$ & $\begin{array}{c}\text { Frekuensi } \\
\text { Relatif }\end{array}$ & Kategori \\
\hline 1 & $32.50-40.00$ & 26 & $86.67 \%$ & Sangat Baik \\
\hline 2 & $25.00-32.49$ & 4 & $13.33 \%$ & baik \\
\hline 3 & $17.50-24.99$ & 0 & $0 \%$ & cukup \\
\hline 4 & $10.00-17.49$ & 0 & $0.00 \%$ & kurang \\
\hline & Total & 30 & $100 \%$ & \\
\hline
\end{tabular}

Distribusi frekuensi skor kompetensi guru menyusun instrumen tes ditampilkan dalam bentuk diagram batang seperti gambardiagram batang berikut ini.

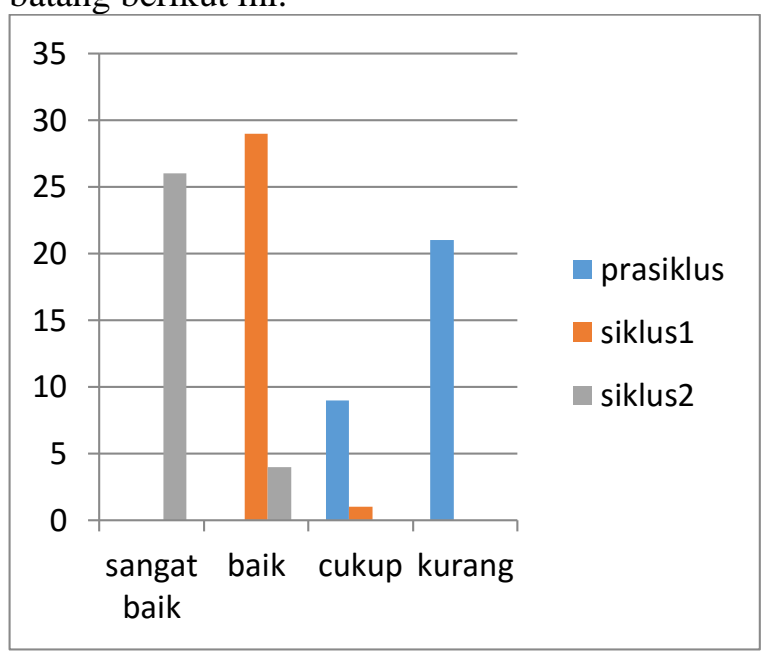

Gambar 1 Diagram Batang

Kompetensi Guru Menyusun

Instrumen Tes pada Siklus
Secara rinci kompetensi guru untuk setiap aspek pada indikator kompetensi menyusun instrumen tes, Tingkat ketercapaian masingmasing guru pada aspek syarat kisi-kisi sangat baik, merumuskan indikator, materi soal, konstruksi soal, bahasa soal, analisis tingkat kesukaran, analisis efektivitas pengecoh, analisis validitas butir soal telah mencapai kategori sangat baik. Aspek yang tidak mencapai kategori sangat baik yaitu analisis daya pembeda analisis reliabilitas soal, kedua aspek tersebut hanya berkategori cukup. Hal ini dapat dilihat pada table 2 berikut ini :

Tabel 5. Tingkat Ketercapaian Setiap Aspek Pada Indikator Menyusun Instrumen Tes Siklus I

\begin{tabular}{llllll}
\hline No & Indikator & Aspek & Skor Total & $\begin{array}{l}\text { Rata-rata } \\
\text { Skor }\end{array}$ & Klasifikasi \\
\hline $\mathbf{1}$ & $\begin{array}{l}\text { Membuat } \\
\text { Kisi-kisi Soal }\end{array}$ & $\begin{array}{l}\text { Syarat Kisi-Kisi yang } \\
\text { Baik }\end{array}$ & $\mathbf{3 4 4 . 0 0}$ & $\mathbf{3 . 8 2}$ & Sangat baik \\
\cline { 3 - 5 } & Merumuskan Indikator & $\mathbf{3 4 1 . 0 0}$ & 3.79 & Sangat baik \\
\hline \multirow{2}{*}{$\mathbf{N}$} & Merangkai & Materi & 332.70 & 3.70 & Sangat baik \\
\cline { 3 - 5 } & Soal & 339.30 & 3.77 & Sangat baik \\
\cline { 3 - 5 } & Konstruksi & 333.10 & 3.70 & Sangat baik \\
\hline \multirow{3}{*}{ Analisis Soal } & Bahasa & Tingkat Kesukaran & 336.00 & 3.73 & Sangat baik \\
\hline & EfektiVitas Pengecoh & 360.00 & 4.00 & Sangat baik \\
\hline & & Daya Pembeda & 273.00 & 3.03 & cukup \\
\hline & Validitas Butir Soal & 342.00 & 3.80 & Sangat baik \\
\hline & & Reliabilitas Soal & 252.00 & 2.08 & cukup \\
\hline
\end{tabular}

Hasil refleksi pertama yaitu pencapaian kompetensi guru menyusun instrumen tes yaitu
26 atau $86,67 \%$ orang guru kompetensi menyusun instrumen tes berkategori sangat baik 
dan 4 atau 13,33\% orang guru kompetensi menyusun instrumen tes berkategori baik. Empat guru yang memiliki kompetensi menyusun instrumen tes tidak mencapai kategori sangat baik adalah responden nomor $6,8,15$ dan 27 .

Tingkat ketercapaian masing-masing guru pada aspek syarat kisi-kisi sangat baik, merumuskan indikator, materi soal, konstruksi soal, bahasa soal, analisis tingkat kesukaran, analisis efektivitas pengecoh, analisis validitas butir soal telah mencapai kategori sangat baik. Aspek yang tidak mencapai kategori sangat baik yaitu analisis daya pembeda analisis reliabilitas soal, kedua aspek tersebut hanya berkategori cukup.

Refleksi kedua yaitu model pelatihan SSOTT telah diterapkan dengan baik. Semua langkah-langkah model pelatihan SSOTT telah dilaksanakan. Model pelatihan SSOTT dengan pendekatan individual lebih efektif meningkatkan kompetensi guru. Suasana pelaksanaan pelatihan dengan pendekatan individual lebih akrab, terjadi dialog antara peneliti, pengawas kolaborator dengan guru peserta pelatihan. Melalui dialog tersebut peneliti dapat mengidentifikasi dan mengatasi kesulitan-kesulitan yang dihadapi oleh guru ketika menyusun instrumen tes.

Kesimpulan dari refleksi pertama dan kedua pada siklus II adalah kompetensi guru menyusun instrumen tes telah melewati kriteria keberhasilan yaitu kompetensi guru menyusun instrumen tes berada pada kategori sangat baik (mendapatkan skor $\geq 32,50$ ) dan jumlah guru yang berada pada kategori sangat baik sebanyak 26 responden atau $86,67 \%$. Peneliti menganggap penelitian ini tidak perlu lagi melanjutkan tindakan ke siklus berikutnya meskipun masih ada kekurangan ketercapaian pada indikator analisis soal yaitu pada aspek daya pembeda butir soal dan reliabilitas soal dan masih ada 4 orang guru kompetensi menyusun instrumen tes berada pada ketegori baik.

\section{Pembahasan Atas Hasil Tindakan}

Pelaksanaan tindakan siklus I dilaksanakan sebanyak tiga kali pertemuan. Siklus I menunjukkan bahwa implementasi pelaksanaan model pelatihan SSOTT masih memiliki kekurangan. Proses pelatihan SSOTT belum adanya dorongan minat guru untuk bertanya ketika mengalami kesulitan terhadap materi pelatihan dan kurangnya bimbingan dari narasumber secara individual ketika memberikan materi pelatihan kepada para guru.
Proses pelatihan yang terjadi pada siklus I adalah pelatihan terlalu terpusat kepada peneliti sebagai narasumber pada saat pelatihan sehingga suasana pelatihan terlihat sangat kaku. Hasil tindakan siklus I, guru yang menjadi subjek penelitian telah memiliki kisi-kisi soal, membuat soal sesuai berdasarkan kisi-kisi soal, dan melakukan analisis soal, tetapi yang menjadi masalah adalah kualitas soal yang dibuat oleh guru masih belum sesuai dengan standar soal yang baik setelah soal tersebut diujicobakan kepada peserta didik hasil analisisnya adalah kualitas soal yang dibuat oleh guru belum baik

Pelaksanaan tindakan siklus II merupakan perbaikan dari pelaksanaan tindakan siklus pertama. Tindakan siklus II bertujuan untuk menyempurnakan kekurangan-kekurangan yang terjadi pada siklus I sehingga kompetensi guru dalam menyusun instrumen tes mencapai ketegori baik. Proses pelatihan yang terjadi pada siklus II berbeda dengan proses pelatihan siklus I. Proses pelatihan tidak lagi terpusat kepada peneliti sebagai narasumber pelatihan. Peneliti melakukan pendekatan secara individual untuk membimbing guru secara intensif sehingga materi pelatihan dapat dipraktikan oleh guru. Melalui pendekatan secara individual, narasumber lebih mengetahui kelemahankelemahan yang dihadapi oleh guru dalam menyerap dan mempraktikkan materi pelatihan. Selain itu dialog dan tanya jawab antara peserta pelatihan, narasumber berjalan dengan lancar. Suasana pelatihan pada siklus II lebih akrab dan tidak kaku.

implementasi model pelatihan SSOTT dapat meningkatkan kompetensi guru guru guru dalam menyusun instrumen tes. Terutama guru yang ada diSD Negeri 003 Teluk Sebong khususnya dan guru- guru yang ada di SDN 003 Teluk Sebongumumnya. Hasil penelitian ini menunjukan bahwa pelatihan dapat meningkatkan kompetensi guru- guru khususnya guru SD Negeri 003 Teluk Sebong dan guru guru yang ada di SDN 003 Teluk SebongKecamatan Teluk Sebong.

\section{SIMPULAN DAN SARAN Simpulan}

Berdasarkan hasil Penelitian Tindakan Sekolah (PTS) dapat disimpulkan sebagai berikut. Berdasarkan hasil penelitian dan pembahasan, dapat ditarik kesimpulan yaitu pada siklus I, kompetensi guru menyusun instrumen tes belum ada yang mencapai kategori baik. 29 atau 96,67\% orang guru kompetensi 
menyusun instrumen tes berkategori baik dan 1 atau 3,33\% orang guru kompetensi menyusun instrumen tes berkategori cukup. Tingkat ketercapaian masing-masing guru pada aspek syarat kisi-kisi yang sangat baik, merumuskan indikator, materi soal, konstruksi soal dan bahasa soal sudah berada pada kategori sangat baik. Aspek yang belum mencapai kategori sangat baik yaitu analisis tingkat kesukaran, analisis daya pembeda analisis efektivitas pengecoh, analisis validitas butir soaldan analisis reliabilitas soal.

Siklus II, pencapaian kompetensi guru menyusun instrumen tes yaitu 26 atau 86,67\% orang guru kompetensi menyusun instrumen tes berkategori sangat baik dan 4 atau 13,33\% orang guru kompetensi menyusun instrumen tes berkategori baik. Tingkat ketercapaian masingmasing guru pada aspek syarat kisi-kisi sangat baik, merumuskan indikator, materi soal, konstruksi soal, bahasa soal, analisis tingkat kesukaran, analisis efektivitas pengecoh, analisis validitas butir soal telah mencapai kategori sangat baik. Aspek yang tidak mencapai kategori sangat baik yaitu analisis daya pembeda analisis reliabilitas soal, kedua aspek tersebut hanya berkategori cukup. Hasil penelitian menemukan bahwa implementasi model pelatihan SSOTT dapat meningkatkan kompetensi guru guru dalam menyusun instrumen tes.

\section{Saran}

Implementasi model pelatihan SSOTT dapat meningkatkan kompetensi guru guru dalam menyusun instrumen tes. Hasil penelitian ini menunjukan bahwa pelatihan dapat meningkatkan kompetensi guru dalam menyusun instrumen tes penilaian yang sangat berguna bagi guru sendiri dan para siswa mereka masing masing. Motivasi yang sudah tertanam khususnya dalam penyusunan intrumen tes hendaknya terus dipertahankan dan ditingkatkan. Seringlah melakukan dialog dan tanya jawab dengan teman sejawat atau kepala sekolah untuk mengatasi semua masalah yang dihadapi di sekolah guna memperlanca proses belajar mengajar dan meningkatkan kopetensi guru

\section{DAFTAR PUSTAKA}

Brinkerhoff, et al. 1983.Program Evaluation:Practitioner's Guide For Trainers and Educators. Boston The Hague Dordrecht Lancaster: Kluwer-Nijhoff Publishing.

Depdiknas. 2005. Undang-Undang Republik Indonesia Nomor 14 Tahun 2005 tentang Guru dan Dosen. Jakarta: Laksana

Dessler, Gary. 2006. Manajemen Sumber Daya Manusia. PT Intan Sejati: Klaten.

Grounlund, Norman E. 1985. Measurement and Evaluation in Teaching Fifth Edition. New York: Macmilan Publishing Company.

Mardapi, Djemari. 2012. Pengukuran, Penilaian dan Evaluasi Pendidikan. Yogyakarta: Nuha Medika.

Siagian, S.P. 2008. Manajemen Sumber Daya Manusia. Jakarta: PT. Bumi Aksara

Sudjana, Nana. 2010. Penilaian Hasil Proses Belajar Mengajar. Bandung: PT Remaja Rosdakarya

Sugiyono. 2011. Metode Penelitian Administrasi. Bandung : Alfabeta

Tim Peneliti Balitbanda Sumut. 2005. Studi tentang Kemampuan Matematika Guru Sekolah Dasar dan Faktor-faktor yang Mempengaruhinya. Medan: Balitbangda Pemprov Sumetera Utara 